\title{
3 \\ Reforming transport planning in Australia
}

\author{
Marion Terrill
}

This chapter considers ways to reframe transport planning in Australia by reorienting debate away from the traditional investment-only focus on big projects to considering transport as an organic enabling system interconnected with many spheres of policy. To date, most transport planners have been preoccupied with planning how people should move about as if they are in control of the system. Planners have devised various ways to move people and freight around more efficiently, including approaches such as 'park and ride', carpooling, avoiding peak hour, utilising freeways, avoiding 'rat-running' and requirements for delivery trucks to deliver at night. All of these approaches have one thing in common: they are attempts to work out what people should be doing and planning how they should move about.

Planning a complex social system is difficult, but it does not stop people from trying to do it. We see this in a lot of different fields. I will address transport planning shortly, but first let me discuss how any complex social system works and how it organises itself. There is a fierce debate going on at present about science and maths training. We have people such as Australia's Chief Scientist saying we need to lift enrolments for core science disciplines at post-secondary levels. We have the Business Council of Australia saying we need to devise a 10-year plan to get more students into tertiary science and technology courses. Their voices are not 
alone, but we could ask another set of questions: why are so many people choosing courses other than science and technology; why are they making the 'wrong choices'; and, who is managing the education system?

The reality is that no one is managing it. People are making their own decisions. The system is organising itself. People are deciding whether to study science and maths, or fashion, or fine art, or law, or nothing at all, on the basis of their own preferences, what they think they will do at the end of it and what they have to pay directly and indirectly. If we do not have enough science and technology graduates, those who do these disciplines will command a higher wage, we will import graduates from countries such as Ireland or China, or people in related fields will upskill. Meanwhile, those people who have studied fashion and fine art are presumably doing a thing they value more, even if getting a job at the end of it is harder. Therefore, our ability to really manage these systems and to get people to do what we want is pretty limited. So, what I want to do in terms of framing is to say that when society tries to solve these complex social problems, the best thing to do most of the time is to try to create the right incentives, then it is not necessary to plan the precise details, as people will figure out what to do and how to adapt to situations.

The concept of the self-organising system is incredibly relevant to transport planning. It is very clear that we need ports and roads and trains, and that government has an important role in ensuring we have the means to move around and that freight can get to and from airports, warehouses and depots. But how do we decide how many we need and where to put these things? This chapter is about how we approach this question. I will discuss the four major levers that are available to government in its transport planning role: investment, pricing, regulation and network management.

As with government, I will start with the investment function. So much of the public debate about transport planning begins and ends with investment. We have recently witnessed former treasurer Joe Hockey invoking the spirit of Joh Bjelke-Petersen as he welcomed the appearance of 165 cranes over the Sydney CBD and even two springing up in Hobart. Meanwhile, in the lead-up to the Canning by-election in Western Australia in 2015, federal opposition spokesman on transport and infrastructure, Anthony Albanese, talked about the government's neglect of infrastructure and how dire that neglect is for increased congestion. 
In an environment of population growth, it is clear there will need to be growth in infrastructure investment, even if the exact nature of what is needed is a lot less clear. So the aspect of investment I will discuss here-which is one that seldom receives much airtime-is the issue of timing. I will start by mentioning a really important marker in the business environment today: the cheapness of money. Yields on 10-year government bonds hit an all-time low in February 2015, of 2.28 per cent. In other words, it has never been cheaper for government to borrow money-not just in Australia, but also around the world. Andy Haldane (2015) from the Bank of England has found that short-term interest rates are at their lowest point since Babylonian times. Money is cheap. If ever there was a time to borrow for transport infrastructure, now is that time.

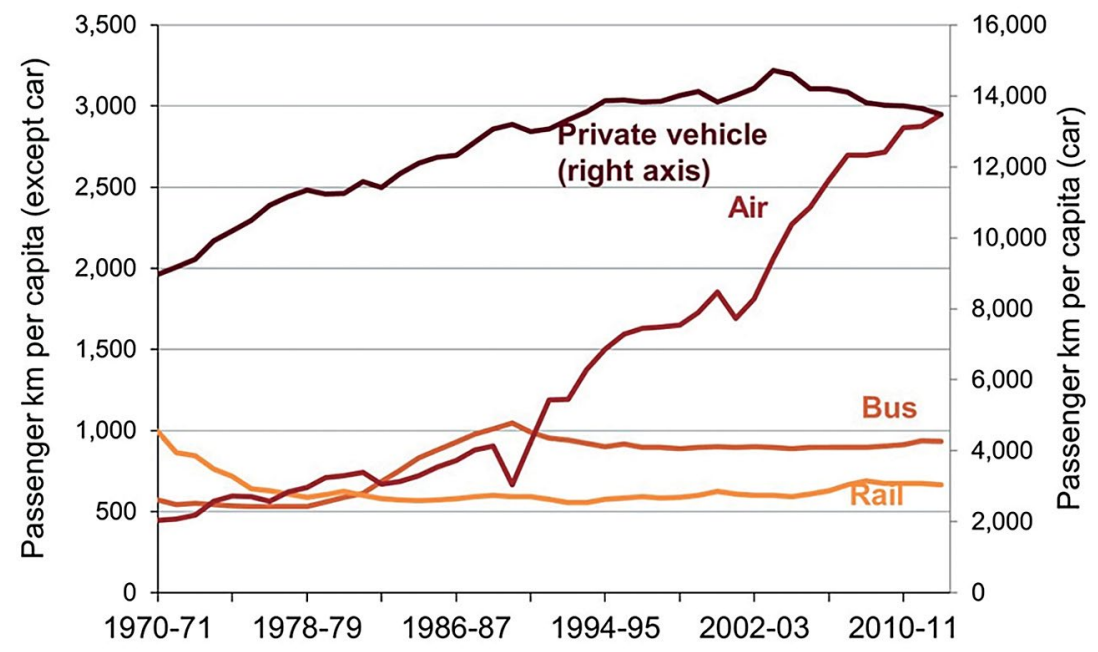

Figure 3.1 Domestic passenger travel per capita

Sources: BITRE (2015: Table T3.1, p. 61); ABS (2014a).

On the other hand, demand for transport infrastructure is changing. Figure 3.1 indicates passenger demand for different types of transport on the basis of per capita distance travelled. It is immediately apparent that the distances people are travelling have flattened, and are beginning to decline slightly after years of growth-most evident in private vehicle travel. Use of other transport modes has increased, but overall domestic distance travelled per capita is 1 per cent lower than it was 10 years ago. The volume of domestic freight per capita has increased reasonably steadily over the past 20 years. It did flatten a bit at the time of the Global Financial Crisis (GFC). And there has been quite an increase in the past 
decade, but it has come mainly from rail, and that has been mainly bulk rail in Western Australia - in other words, iron ore. Moving to an aggregate level, and taking account of population growth running about 1.4 per cent at last count (ABS 2016c), passenger car travel is now levelling off, air travel is still booming and bus and rail are growing more slowly. The volume of domestic freight has continued to increase in aggregate.

This suggests that population growth alone is not a reliable indicator of investment need, given the changing nature of travel demand across the modes.

Another consideration, as indicated in Figure 3.2, is the level of existing investment. This shows that while government spending has recently slowed, it remains well above the level of 2004, when current rapid growth began. The figure indicates that the value of engineering construction work completed and the value of transport infrastructure building over the past decade have in fact been the highest since the Australian Bureau of Statistics (ABS) began collecting this information. They peaked in 2012, but declined over the next two years. There is some GFC stimulus spending included in the figure; nevertheless, the level of investment over the past 10 years has been considerable.

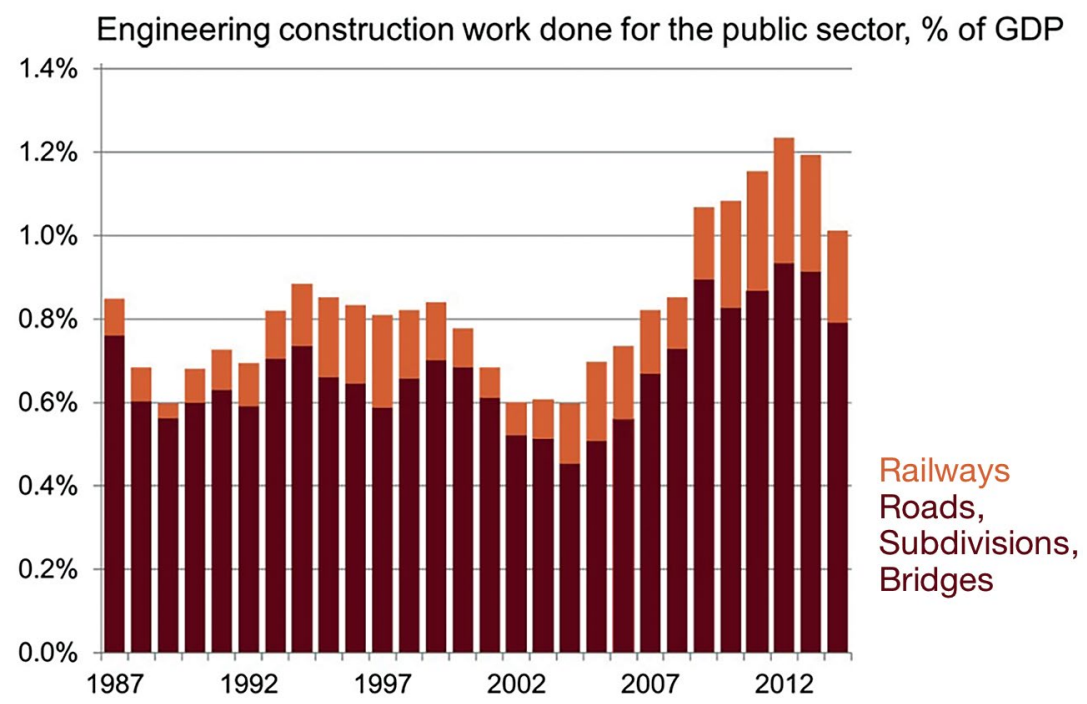

Figure 3.2 Government spending on transport infrastructure Sources: ABS (2016a; 2016b: Table 11). 
Why does it matter today that governments have spent so much in the past decade? It matters because of the debt that is now sitting on state and territory balance sheets for that spending. Over the seven years to 2013-14, interest and depreciation costs as a percentage of state revenue increased from about 6 per cent to 9 per cent, and are estimated to remain close to 9 per cent over the forward estimates period, as Figure 3.3 indicates. Interest expenses have increased more quickly than depreciation. The increase is equivalent to states spending about 0.5 percentage point of gross domestic product (GDP) more to cover the infrastructure spending of previous years, and this is despite extremely low interest rates.

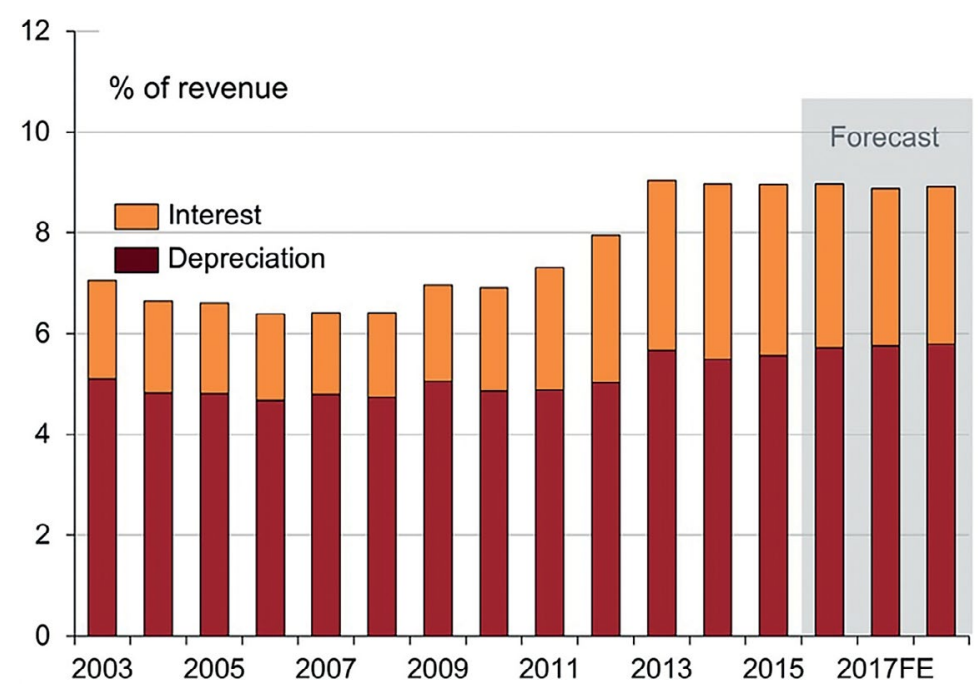

Figure 3.3 State and territory depreciation and interest costs Source: ABS (2014b), cited in Grattan (2014).

So what should Australian governments do about their transport investment? The states are taking a range of very different positions. The Victorian Treasurer, Tim Pallas, made headlines by contemplating debt financing public infrastructure (Davey 2015), and largely on the basis that Victoria's 10-year borrowing rate is 2.65 per cent-close to the cheapest it has ever been. The Queensland Government has indicated that it may be prepared to borrow money to fund needed public transport infrastructure if the Commonwealth does not help (APP 2015), and that is essentially because Queensland is not participating in asset recycling. On the other hand, the NSW Government has brought forward $\$ 600$ million of infrastructure spending, because it is benefiting from a stamp 
duty windfall from the Sydney housing boom as well as $\$ 20$ billion from electricity privatisation (Gerathy 2015). Western Australia is pushing back its investment program, with its iron ore royalties dropping precipitously (Government of Western Australia 2015: 5).

In summary, my reading of the situation is that governments have built a great deal of infrastructure over the past 10 years, and that has corresponded with the mining boom. However, state governments have essentially competed for construction resources in that time. Now that private investment is falling, the public sector has already committed to substantial transport infrastructure construction and is not especially well placed to take advantage of this buyer's market; therefore, this does not seem to have been the wisest way to run infrastructure policy. On the other hand, one might say, 'What is done is done, and what should we do now?' It is very clear that we should still be open to funding transport infrastructure if there is a good cost-benefit ratio; admittedly, this is a big 'if'.

Turning to the second lever-pricing — the biggest issue is road pricing, and it is hard to spend much time in transport circles without coming up against this issue. Expert opinion from the Henry review and the Productivity Commission to the Harper review has all lamented the inefficient way we fund and manage our roads. Road pricing is essentially about explicitly charging for the costs that one vehicle's road usage imposes on others. Typically, this focuses on one of two things: the cost of maintenance due to wear and tear (and this relates largely to heavy vehicle usage) and the cost of congestion to regular users and potentially other externalities. This concerns all vehicles in particular places and at particular times.

The congestion argument may be summarised as follows: when people suffer in bumper-to-bumper traffic, they conclude that we need to build more highway lanes; but when governments reflexively add capacity to solve congestion, it helps, but only temporarily. Before long more traffic builds up, and once again we are trying to solve the same problem. A study in the United States found worsening congestion in 99 of 100 places studied since 1994, even though in 92 of those places there was an increase in the amount of roadway miles per capita. In fact, building more roads to try to move vehicles faster can make traffic worse. Focusing on the 'rush-hour peak' also ignores the much greater availability of the road system in 'off-peak' periods, when far greater numbers of trips 
could be taking place. The potential value of moving some trips off peak is high. Nevertheless, such road-building strategies can also occur at the same time as a relative underfunding of public transport, which ironically leads people to rely more on private cars because of poor performance or services in public transport networks.

An interesting case involving the introduction of road user charging has occurred over the past decade in Stockholm, Sweden. One of the architects of Stockholm's congestion charging, Jonas Elliasson, sought explicitly to counter the fear that ministers feel about congestion charging by careful consideration of the rollout of the scheme. There were four major findings from this Swedish experiment.

First, a very modest initial charge in a trial period can make a big difference to acceptance. In Stockholm, the charge of $€ 1$ to $€ 2$ for people to travel to Stockholm's CBD reduced traffic in a heavily congested area by 20 per cent, with people's response immediate and rather pronounced. Second, the experiment found that the relationship between traffic flow and congestion is not linear; a reduction of 20 per cent in vehicle numbers would reduce congestion by far more than 20 per cent. Third, surveys found that people in Stockholm were fiercely against the pricing program at first, with reports of up to 70 per cent opposition. However, by the time the trial was conducted, this had reversed - to 70 per cent in favour of the pricing program. What this means in terms of transport planning is that 70 per cent of people in Stockholm wanted to pay for something that had previously been 'free'. Fourth, experts found that road users adapted their attitudes and behaviour so thoroughly they could not even remember what they used to believe; they thought they had supported congestion charging all along!

My reflection on this experiment is that we should not assume that congestion pricing is impossible. The experience overseas suggests that governments in Australia are far too timid. Given that the pay-off from congestion pricing has the potential to be very high, we could achieve much more functionality in transport usage with much less political pain than the political class fears. I suggest the most useful message is that we should get on with convincing them of the benefits of congestion charging. 
The third lever is regulation. Transport regulation generally has the objective of enabling the best use of scarce resources in moving people and things around, and, in more commercial settings, this typically means at the lowest cost. But regulation does not always lead to cost containment. I will cite two examples of 'skewed' regulation that focus partly on the objectives of transport accessibility, but also bring in other political objectives that may ultimately determine the regulatory settings: ports and ride-sharing.

Ports play an important, if not particularly obvious, role, with the cost of port services an important component of the cost of goods and services, which ultimately falls on either consumers or exporters. There are several ways that regulations affecting ports could be improved.

First, when ports are put up for sale or long-term lease, state governments should avoid the temptation to inflate the sale price without retaining control of ongoing user charges. In Melbourne recently, the Australian Competition and Consumer Commission (ACCC) made a forceful submission to the Victorian Legislative Council on legislation before the Victorian Parliament to lease the Port of Melbourne on a 50- to 70year lease (ACCC 2015). As the ACCC emphasised, governments have a strong incentive to structure their privatisation process to maximise the sale price, but this price—if it is high — will flow through to port users into the future. In fact, the ACCC went so far as to say that the government's privatisation policy could be considered to effectively impose a tax on future generations of Australians. The government has proposed a 50- to 70-year lease with price controls for the first 15 years, but, after that, the process remains unclear.

Second, governments should minimise the fees charged to ports and port operators. Between 2012 and 2016, there was a $\$ 75$ million licence fee for the Port of Melbourne-which, in other words, is a tax on trade. Fees and charges like this are simply passed on. The chief executive officer (CEO) of freight logistics company Asciano, John Mullen, has said: 'If a port owner has to put up prices to try and get a return, ultimately the consumer, or manufacturers, or exporters are paying that bill' (Roberts 2014). Similarly, the Port of Melbourne recently imposed a rent review on one of its stevedores, DP World, asking for a staggering 767 per cent increase in the rent it pays, leading to a bitter dispute (Financial 
Review 2015). The firm currently pays $\$ 16$ to $\$ 18$ per square metre. Following the dispute, the firm will now be paying $\$ 20$ per square metre, rather than the proposed $\$ 120$.

A third improvement that could be made to the regulations affecting ports is shipping regulation. The Commonwealth could overturn the current rules that make it perfectly legal for groupings of two or more shipping lines to band together and charge what is known as pan-Australian freight rates. Under such arrangements, shipping companies charge the same rate at each port of call, meaning there is no incentive for the more expensive ports to bring their costs down, and there is no advantage to running a lean operation. Effectively, this means the leaner ports are subsidising the less efficient ports. These types of changes would lower the input costs of businesses that want to export and the costs of goods that go to Australian households and businesses. Therefore, there are potential benefits to be gained in regulating ports.

My second example is ride-sharing through companies such as Ubercurrently very topical. During 2015, taxi and hire car operators were planning rolling 24-hour strikes and rallies across the major cities in Australia. Most of the debate about Uber and ride-sharing more generally focuses on taxi regulation. The Victorian taxi industry has experienced more reforms than elsewhere. Taxi regulations cover four key areas: safety, availability, customer service and price. While it is likely that all states over time will narrow the gap between ride-sharing and taxis, it is not clear how long this will take. Nevertheless, the biggest barrier is likely to be the value of perpetual licences, which governments have issued over the years and which are essentially a right to operate a taxi. In Melbourne, taxi licences have traded at about \$290,000, and in Sydney, \$390,000 (Taxi Services Commission 2017; RMS 2017).

Figure 3.4 indicates that passengers are already voting with their feet. I have taken data from the United States, where ride-sharing is a little more established than it is here, and what you can see is the first panel shows the steady drop in the number of taxi trips taken in San Francisco, with the introduction of transport network company regulation making little or no difference to the trend. Similarly, in Australia, despite the uncertain legal status of Uber, in its first six months of operation, 11 per cent of Sydney residents used the service. It has only become more popular since then; the price is competitive and many people believe it offers better customer service. 


\section{Taxi revenue and licence values fall sharply once ride-sourcing takes off}
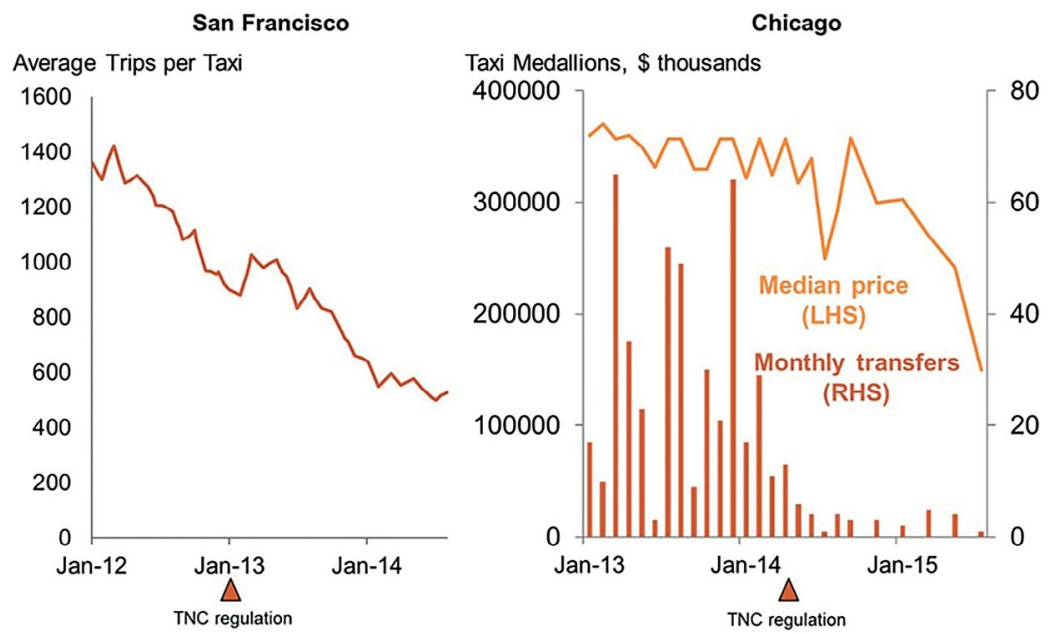

Figure 3.4 Impact of ride-sharing on taxi revenue and licence values

Note: TNC = transportation network companies.

Sources: Chicago Data Portal (2018); DataSF (2018).

The right-hand panel in Figure 3.4 shows what happened in Chicago to the price of 'taxi medallions', which are similar to Australia's perpetual licences. It is likely a similar drop could be experienced in Australia. The Independent Pricing and Regulatory Tribunal (IPART) in New South Wales (NSW) has estimated that 15-20 per cent of the price of a taxi fare is being transferred to the licence owner as economic rent. While taxi regulation is really important to Uber, it is not the only kind of regulation that matters. There are two other important elements: tax and employment law. On tax, Uber is taking the Australian Taxation Office (ATO) to court over whether even occasional ride-share drivers should register for the goods and services tax (GST), with Uber arguing its drivers are members of the sharing economy and should be treated the same as Airbnb hosts, who do not have to register for GST until their turnover reaches $\$ 75,000$ a year. On the other hand, the ATO is saying, 'You are providing taxi services, so you have to pay it from the first dollar, as taxis do.'

On employment law there has been recent publicity in the United States concerning a San Francisco judge who ruled that Uber drivers in California were employees, which opens the door to benefits such as overtime pay and reimbursement for expenses. Here in Australia, this issue is not entirely clear. It is arguable that Uber drivers are more like contractors in the sense that they 
choose how much work, if any, they do, and they do not wear a uniform or have a livery. Further, the GST decision indicates that they are regarded more like contractors. Uber does set rates of pay and drivers can drive for Uber only if they are authorised to use its app. This is still very much a 'grey' area.

What does all this mean for transportation regulation? Getting more trips from the existing cars on the road does improve capital productivity. Enabling people to work-including having people who would have worked just a little or just a little more than they do at presentis employment boosting. This is good for the individual, they are good for the economy and there is no compelling reason not to establish the minimum sufficient regulation to give ride-sharing the scope to operate legally. The only sticking point is the political problem of the declining value of perpetual taxi licences, and this really depends on how courageous governments are prepared to be.

The fourth and final lever available to government is network management. This is a low-glamour, but high-return, lever. Figure 3.5, compiled by Infrastructure Australia, reports an enduring finding. A similar finding came out of the Eddington Transport Study in the United Kingdom. It is that small and medium-sized projects tend to have higher benefit-cost ratios than many of the mega projects that are so appealing to so many governments.

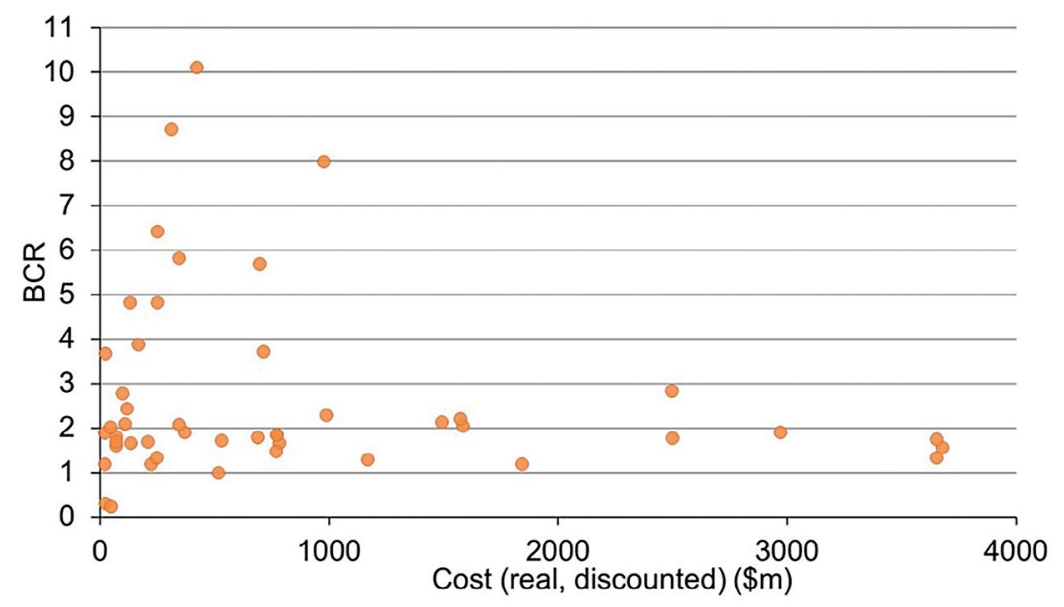

Figure 3.5 Economic returns of smaller schemes compared with larger schemes (projects submitted to Infrastructure Australia)

Note: $\mathrm{BCR}$ = benefit-cost ratio.

Source: Infrastructure Australia (2013). 
An example of this is Melbourne's rail network. This network is not particularly small, but close to $\$ 1$ billion has been spent on maintenance and renewal over the past four years-after what has been described as decades of neglect. There are a few issues here. One is the outdated signalling, which is a big source of delays in the system. Some signals are 100 years old, with a design life of much less than this. They are prone to failure, they are expensive to maintain and there are few people left who know how to maintain them.

Similarly, the network includes some very complex rail junctions. What this means is that a failure or delay on one part of the track cascades through the network. As the different lines converge on to the city loop, throughput is limited by the capacity of the loop, and where lines converge the speed is limited to $25-40$ kilometres an hour. This is an important facet in the relatively poor performance of the Melbourne network during peak periods.

A third problem is a lack of adequate electrical power, particularly in the inner city. All trains bought this century have had to be detuned to perform to the same specifications as the older and slower trains, which require less voltage. The newest trains perform very badly under this low voltage. These impediments are not small things, but they are also not mega projects, and so are not so appealing to politicians in terms of the publicity opportunity. But they are not about building new things so much as about getting more from existing assets. This is also a prominent focus in NSW, where the state is spending $\$ 1$ billion on upgrades to the existing road network, including works to relieve congestion at pinch points across the capital, Sydney, to extend clearways, make improvements to real-time traffic management and so forth.

In a similar vein is the issue of maintenance across the entire transport network. It is difficult to make general comments about the overall state of maintenance of Australia's transport network, but Figures 3.6 and 3.7 are indicative. 


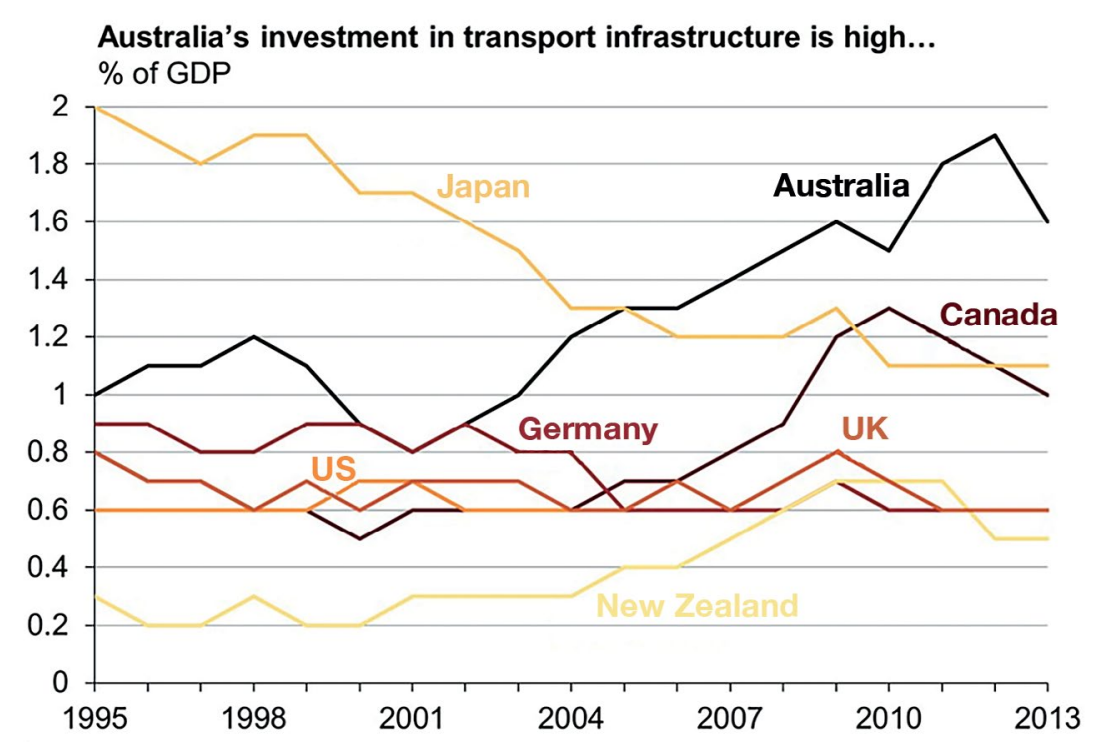

Figure 3.6 International comparison of Australia's investment in transport infrastructure Source: OECD (2016).

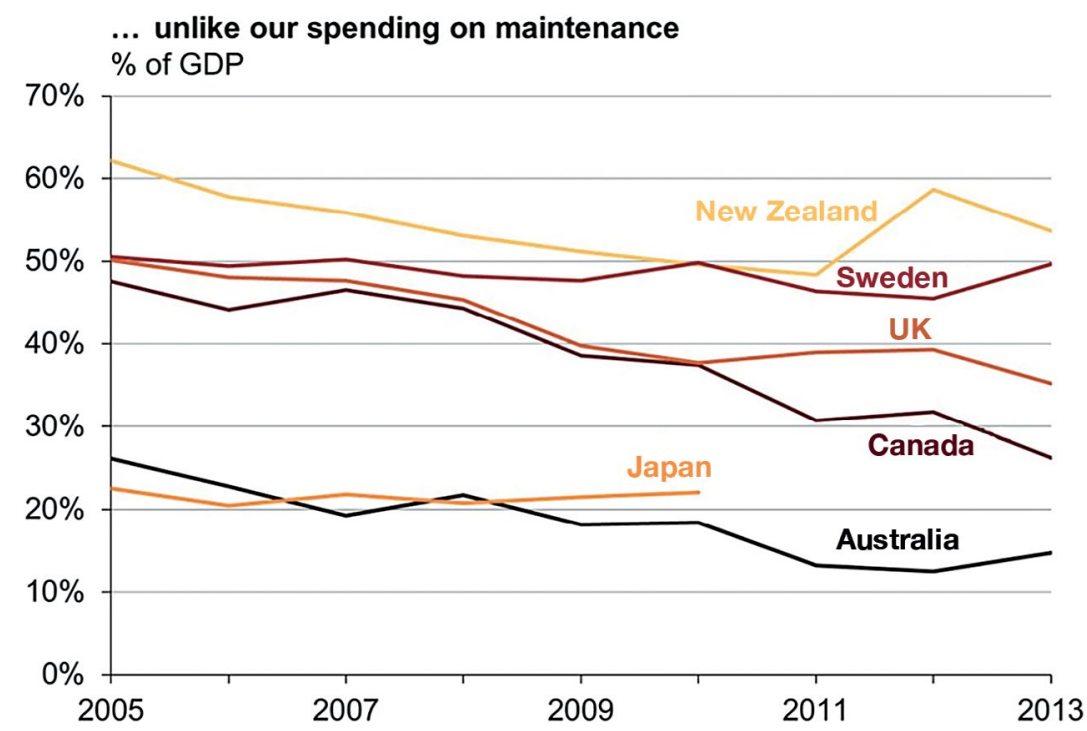

Figure 3.7 International comparison of Australia's maintenance expenditure on transport infrastructure

Source: OECD (2016). 
Figure 3.6 shows that, from 2004, (new) Australian investment in transport infrastructure increased dramatically, and it remained at very high levels compared with other Organisation for Economic Co-operation and Development (OECD) countries. On the other hand, Figure 3.7 shows our maintenance spending on transport infrastructure seems to be at the bottom of the pack of OECD countries. Without being a comprehensive study, this suggests our maintenance spending — or maintenance activitymay not be keeping up with our new building; and perhaps we are more keen to build new infrastructure than to look after what we already have. Essentially, the points to be made about network management are that we should 'sweat' the assets, we should be open to small and medium investments as well as big ones and we should set the maintenance budget with some reference to the value of the underlying assets.

\section{Conclusion}

Our thinking about transport planning is best when we set the broad structure of the system, but avoid trying to determine the detail of how we want businesses and individuals to respond. In this chapter, I have argued that in relation to transport planning the challenge is to push back from an investment-only focus and a desire to build big, heroic projects. Transport, after all, is an enabling service; it is not something we generally value in its own right. We value it as it enables us to do other things that we care about. This means it does not really have its own agenda, but is part of many other agendas.

We should remember that we have at our disposal not just the investment lever, but also three other important levers, which should be fully exploited in creating the transport system: pricing, regulation and network management. In the meantime, the message for policymakers is to stop counting cranes on the skyline.

\section{References}

AAP. (2015). Labor will break debt promise: Qld oppn. News.com.au, 12 June. Available from: www.news.com.au/national/breaking-news/borrowingwould-break-promise-qld-oppn/news-story/0501932a17791fc9c950c24512 339ad1 (accessed 20 July 2018). 
Australian Bureau of Statistics (ABS). (2014a). Australian Historical Population Statistics. Canberra: ABS. Available from: www.abs.gov.au/ausstats/abs@.nsf/ $\mathrm{mf} / 3105.0 .65 .001$ (accessed 20 July 2018).

Australian Bureau of Statistics (ABS). (2014b). Government and Finance Statistics, Australia, 2012-13. Cat. no. 5512.0. Canberra: ABS. Available from: www.abs.gov.au/Ausstats/abs@.nsf/0/51DE444E27EF9358CA257E4300 117E05?OpenDocument (accessed 20 July 2018).

Australian Bureau of Statistics (ABS). (2016a). Australian National Accounts: National Income, Expenditure and Product, December. Cat. no. 5206.0. Canberra: ABS. Available from: www.abs.gov.au/ausstats/abs@.nsf/mf/5206.0 (accessed 4 April 2017).

Australian Bureau of Statistics (ABS). (2016b). Engineering Construction Activity, Australia, Dec 2015. Cat. no. 8762.0. Canberra: ABS. Available from: www.abs.gov.au/Ausstats/abs@.nsf/0/B464AA38E5436D56CA257FE 000173850? OpenDocument (accessed 20 July 2018).

Australian Bureau of Statistics (ABS). (2016c). Regional Population Growth, Australia, 2014-15. Cat. no. 3218.0. Canberra: ABS. Available from: www.abs. gov.au/ausstats/abs@.nsf/Previousproducts/3218.0Main\%20Features40201415 ? opendocument $\&$ tabname $=$ Summary $\&$ prodno $=3218.0 \&$ issue $=2014-$ $15 \&$ num $=\&$ view $=($ accessed 20 July 2018).

Australian Competition and Consumer Commission (ACCC). 2015. ACCC submission to the inquiry into the proposed lease of the Port of Melbourne. 10 September. Available from: www.accc.gov.au/system/files/ACCC $\% 20$ submission $\% 20$ to $\% 20$ the $\% 20$ inquiry $\% 20$ into $\% 20$ the $\% 20$ proposed $\% 20$ lease $\% 20$ of $\% 20$ the $\% 20$ Port $\% 20$ of\%20Melbourne_0.pdf (accessed 20 July 2018).

Bureau of Infrastructure, Transport and Regional Economics (BITRE). (2015). Yearbook 2015: Australian Infrastructure Statistics. Canberra: BITRE. Available from: bitre.gov.au/publications/2015/files/BITRE_yearbook_2015 _full_report.pdf (accessed 4 April 2017).

Chicago Data Portal. (2018). Public passenger vehicle licenses. Chicago Data Portal. Chicago: City of Chicago.

DataSF. (2018). Website. Available from: datasf.org/opendata/ (accessed 20 July 2018).

Davey, M. (2015). Victoria's economy 'strong enough to handle debt to fund infrastructure'. The Guardian, 27 August. Available from: www.theguardian. com/australia-news/2015/aug/27/victorias-economy-strong-enough-tohandle-debt-to-fund-infrastructure 
Financial Review. (2015). DP World wins rent battle with Port of Melbourne. Financial Review, 3 August. Available from: www.afr.com/business/transport/ dp-world-wins-rent-battle-with-port-of-melbourne-20150803-giqddz (accessed 20 July 2018).

Gerathy, S. (2015). NSW budget 2015: Six things we already know. ABC News, 22 June. Available from: www.abc.net.au/news/2015-06-22/nsw-budget2015-six-things-we-already-know/6562326 (accessed 20 July 2018).

Government of Western Australia. (2015). 2015-16 Budget: Economic and fiscal outlook. Budget Paper No. 3, May. Available from: www. parliament.wa.gov.au/publications/tabledpapers.nsf/displaypaper/3912914 aef7f3f5176e784f348257e45002d38a5/\$file/2914.pdf (accessed 20 July 2018).

Grattan Institute. (2014). Budget Pressures on Australian Governments. Melbourne: Grattan Institute.

Haldane, A. (2015). Speech to the Open University, 30 June. Available from: www.bankofengland.co.uk/-/media/boe/files/speech/2015/stuck.pdf?la= en\&hash=3247D34307D99E8E4E11E5B890837AD6C6CAEFFB (accessed 20 July 2018).

Infrastructure Australia. (2013). Infrastructure Australia's submission to the Productivity Commission Inquiry into Public Infrastructure - Submission. December. Available from: infrastructureaustralia.gov.au/policy-publications/ publications/IAs-submission-to-the-Productivity-Commission-Inquiry-intoPublic-Infrastructure-Submission.aspx (accessed 20 July 2018).

Organisation for Economic Co-operation and Development (OECD). (2016). Transport: Infrastructure Investment. Paris: OECD. Available from: data.oecd. org/transport/infrastructure-investment.htm (accessed 4 April 2017).

Roads \& Maritime Services (RMS). (2017). Sydney Metropolitan Transport District taxi licence transfers: January 2008 - October 2017. NSW Government. Available from: www.rms.nsw.gov.au/about/corporate-publications/statistics/ public-passenger-vehicles/licence-transfers/sydney.html (accessed 20 July 2018).

Roberts, G. (2014). Port privatisations hurt economy: Asciano. Sydney Morning Herald, 7 May.

Taxi Services Commission. (2017). Metropolitan taxi-cab licence transfer prices: 1 September 2015 - 31 January 2017. Victoria State Government. Available from: taxi.vic.gov.au/_data/assets/pdf_file/0003/18192/Licence-TransferValues.pdf (accessed 20 July 2018). 
This text is taken from Road Pricing and Provision: Changed Traffic Conditions Ahead, edited by Michael de Percy and John Wanna, published 2018 by ANU Press, The Australian National University, Canberra, Australia.

doi.org/10.22459/RPP.07.2018.03 